\section{Spatial Usage and Qualifications of Outdoor \\ Recreation Areas in Primary Schools: A Case Study From Üsküdar}

Selda Cansu Temel¹ ORCID: 0000-0001-5712-9778

\section{Keywords}

primary school, recreation areas, schoolyard, İstanbul

\section{Abstract}

The education system in Turkey has shown many changes over the years. Curriculum applied, examination system, schools' identity change very often; however, our educational structures are not always able to respond to these changes. As a result of the lack of space, apart from the classrooms, the units used by students in some schools are restricted thus the number of classrooms is increased as a solution. This situation leads to higher-rise buildings and less open spaces used by more students. As a result of the observations and researches carried out in the schools, it has been noticed that the places used for breaks have architectural disadvantages as well as inadequacies. The study has been handled within the framework of this outcome. In this study, it is aimed to analyze the planning and design criteria of primary school gardens in terms of national, international and academic standards, and to determine their proficiency levels. One of the points that are considered to be incomplete in the literature in this regard is the scarcity of studies on primary school gardens in Istanbul, which has the greatest urbanization problem in our country as being the most populous city of Turkey. In this direction, the study aimed to contribute to the literature by examining the public primary schools in Üsküdar district of Istanbul. In the field study, quantitative and qualitative research methods were used together. Following the supply of the project drawings of the schools, on-site observation and sketch studies were carried out on different days and hours. As a result of the study, the current situation and deficiencies in school gardens were identified.

\section{Article Information}

Received: 29.09.2019

Accepted: 22.01 .2020

Available Online: 28.01.2020

Article Info: This study was produced from the master's dissertation, titled "Site Plan Decisions of Primary Schools and Effect on the Design of OpenClosed Break Areas as a Place of Education" at the Department of Architecture, Mimar Sinan Fine Arts University.

1. Department of Architecture, Karabük University, Karabük, Turkey, seldacansutemel@karabuk.edu.tr 


\section{İlkokullarda Açık Teneffüs Alanlarının \\ Mekansal Kullanımları ve Yeterlilikleri Üzerine Bir İrdeleme: Üsküdar Örneği}

Selda Cansu Temel ${ }^{1}$, ORCID: 0000-0001-5712-9778

$\ddot{O} z$

Türkiye'de eğitim sistemi yıllar içerisinde pek çok kez değişim göstermiştir. Uygulanan müfredat, sınav sistemi, okulların kimliği çok sık değişmekte; buna karşılık eğitim yapılarımız bu değişime her zaman yanıt verememektedir. Mekân yetersizlikleri sonucu, bazı okullarda öğrencilerin ders dışı kullandıkları birimler kısıtlandırılmakta ve böylelikle derslik mekânları arttırılmaktadır. Bu durum, daha çok öğrencinin kullandığı daha yüksek katlı yapılar ve daha az açık alanları beraberinde getirmektedir. Okullarda yapılan gözlem ve araştırmalar sonucu, teneffüs mekânlarının mimari olumsuzluklar ve yetersizlikler barındırdığı fark edilmiştir. Çalışma bu tespit çerçevesinde ele alınmıştır. İlkokul bahçelerinin planlama ve tasarım kriterlerinin ulusal, uluslararası ve akademik standartlar bakımından analizi yapılarak, yeterlilik düzeylerinin belirlenmesi amaçlanmaktadır. Bu doğrultuda literatürde eksik olarak görülen noktalardan biri ülkemizde kentleşme problemlerinin en çok görüldüğü, en kalabalık şehrimiz olan İstanbul'da yer alan ilkokul bahçeleri hakkında yapılan çalışmaların azlığıdır. Çalışma bu doğrultuda İstanbul ilinin Üsküdar ilçesinde yer alan resmi ilkokulları inceleyerek literatüre katkı sağlamayı hedeflemektedir. Gerçekleştirilen alan çalışmasında nicel ve nitel araştırma yöntemleri birlikte kullanılmıştır. Okulların proje çizimlerinin temininin ardından, farklı gün ve saatlerde yerinde gözlem ve eskiz çalışmaları gerçekleştirilmiştir. Çalışma sonucunda, okul bahçelerindeki mevcut eksiklikler tanımlanmıştır.

\section{Anahtar Sözcükler}

ilköğretim okulu, rekreasyon alanı, okul bahçesi, İstanbul

Makale Bilgileri

Alındı: 29.09.2019

Kabul edildi: 22.01 .2020

Erişilebilir: 28.01.2020

Makale Bilgisi: Bu çalışma, yazarın Mimar Sinan Üniversitesi, Mimarlık Bölümünde yapmış olduğu, "İlköğretim Okullarının Vaziyet Planı Kararları ve Bir Eğitim Mekanı Olarak Açık-Kapalı Teneffüs Alanlarının Tasarımına Etkisi" isimli yüksek lisans tezinden üretilmiştir.

1. Mimarlık Bölümü, Karabük Üniversitesi, Karabük, Türkiye, seldacansutemel@karabuk.edu.tr 


\section{INTRODUCTION}

In an educational structure, open spaces and break time activities are as important as lessons. For the children, who goes back and forth between school and home, school is very important as a playground and recreation area. Some educators say that the best time to observe and recognize children is the break time as it is when a child can feel free and show his real character. The experience and knowledge gained by living and playing during recess also plays a great role as much as the information gained from school and other educational tools. The most preferred activity for children of primary school age in their spare time is playing games. According to Özgen and Aytuğ (1992), the child provides the development of emotional, physical, social being emotions by playing games and establishes a relationship with the environment. The child develops his individualization and socialization together by recognizing his experimental needs during the game and recognizes nature (Erdönmez, 2007). During the game, child satisfies his experimental needs and develops his individualization and socialization together and recognizes nature (Erdönmez, 2007). For children who are forced to live among concrete cities, school gardens are one of the rare playgrounds in the city. However, as a result of the observations, it was found that open breathing areas in schools could not respond to user needs. While trying to eliminate spatial deficiencies in schools; the need for children and breathing is placed in the second plan. Generally designed as monotonous and boring, school gardens are often quite isolated from nature. However, natural environments are environments where children can spend more energy, develop their motor skills and socially interact with other children and are generally less restrictive than their homes and schools.

In addition to enabling children to be physically and psychologically healthy, the planning of qualified school gardens also makes children sensitive and protective individuals towards the environment, nature and people. The school is a powerful tool in instilling environmental awareness. In his study in a primary school, Bradley (1995) organized the garden with students, parents and teachers as an area where plants are grown, time is spent in the natural environment and basic ecological information is obtained, and as a result, he observed that the vandalism movements, not only in the primary school yard, but also in the area where the primary school was located, were reduced and environmental awareness increased (Erdönmez, 2007). Some studies investigating environmental behaviors have shown that children who are interested in nature and who are actively involved in care are more concerned and responsible towards their environment (Bunting and Cousins 1985; Harvey 1989; Kellert 1985).

As a result of the literature research carried out in Turkey, It was found that the school gardens were insufficient in size and didn't contribute to the development of children despite the 
importance of the school gardens' designs. In their study in which they examined the school gardens in Çanakkale city center, Kelkit and Özel (2003, 240-246) found that existing schools were inadequate in terms of standards. Özdemir and Yilmaz (2008, 287-300), as a result of their studies in Ankara, determined that most school gardens were inadequate for both playground and physical activities. Aksu and Demirel (2011, 40-46) examined the current physical condition of 35 elementary school gardens in Trabzon city center and found that the designs of school gardens were underestimated. Yllmaz and Ertürk (2016, 45-55) in their studies in Çanakkale, concluded that the sizes of the school gardens were not sufficient, landscape architecture design principles were not utilized in the planning process and that plant elements and reinforcement elements were insufficient. This study, which is tackled specifically for break time spaces in primary schools, has been tried to be developed in line with the scientific research mentioned above.

\section{OUTDOOR RECREATION AREAS IN PRIMARY SCHOOLS AND THEIR SPATIAL USAGE}

The school gardens are used by different age groups with different expectations and needs. Many functions such as recreation, sports and playgrounds, ceremonial area, parental waiting area, open classrooms, green spaces, walking and promenade areas should be located and separated in the school yard. According to Karabey (2014), this separation should be in the form of separation of functions, then the age groups.

There are differences of opinion about the size of the area that will cover all functions in schools depending on many variables. The importance given to school gardens varies between countries and thus different design criteria emerge. The parcel area per student is $40 \mathrm{~m}^{2}$ in Bulgaria, $30 \mathrm{~m}^{2}$ in Germany, $25 \mathrm{~m}^{2}$ in the UK, $20 \mathrm{~m}^{2}$ in the USA, $16 \mathrm{~m}^{2}$ in Poland and $15 \mathrm{~m}^{2}$ in France and China (Çetiner, 1972, citing Özyaba, 1998).

Within the framework of "Regulation on Principles of Reconstruction to the Plan and Changes" term, which was issued based on Zoning Law 3194 in Turkey, the minimum field size for elementary schools was determined as $3500-5000 \mathrm{~m}^{2}$. In addition, an open area of $4 \mathrm{~m}^{2}$ per capita for primary education for citites with the population up to 45000 , and $4.5 \mathrm{~m}^{2}$ per capita for cities with a population of more than 45000 was envisaged (Özyorgun and Batuk, 2007). According to the Ministry of National Education Directive, in the calculation of the garden area the following sizes are used; $5 \mathrm{~m}^{2} /$ student for first 36 students, $3 \mathrm{~m}^{2} /$ student for second 36 students, $2.5 \mathrm{~m}^{2}$ / student for third 36 students, $2 \mathrm{~m}^{2}$ / student for 109-1000 students, $1.5 \mathrm{~m}^{2} /$ student for 1001 2000 students and for more than 2001 students $1.2 \mathrm{~m}^{2}$ / student (Standards Code Related to Private Educational Institutions, 2017).

Looking at the situation in other countries, it is seen that they set standards for school areas larger than the conditions of our country. In the Netherlands, the indoor area per student is $3 \mathrm{~m}^{2}$ and the minimum land size is $15-20 \mathrm{~m}^{2}$ per student. In Sweden, a playground area of $10 \mathrm{~m}^{2}$ per student is determined in small schools and $5 \mathrm{~m}^{2}$ in large schools, and a plot size of $800 \mathrm{~m}^{2}$ per class including playgrounds in urban schools and $600 \mathrm{~m}^{2}$ per classroom in parks associated with parks is allowed. In Germany, the total land area is $25-30 \mathrm{~m}^{2}$ per student, except for sports fields. In England, the area where a primary school will be established is $4000 \mathrm{~m}^{2}$ for $121-160$ students, $5000 \mathrm{~m}^{2}$ for 200- 
400 students, and $5500 \mathrm{~m}^{2}$ for 241-280 students. Primary school playgrounds organized in England according to the number of children over the age of 8 have been determined as $2000 \mathrm{~m}^{2}$ for 1-50 students, $6000 \mathrm{~m}^{2}$ for $121-200$ students and $12000 \mathrm{~m}^{2}$ for more than 280 students. The area per student is $2.14 \mathrm{~m}^{2}$ for $1-75$ students, $4.65 \mathrm{~m}^{2}$ for the first 30 students for $76-120$ students, $1.95 \mathrm{~m}^{2}$ for other students, $4.65 \mathrm{~m}^{2}$ for the first 40 students for 121 and above students and for the other students, this figure is $1.58 \mathrm{~m}^{2}$. (Zengin, 2001).

Considering the functions it contains, school gardens consist of a ceremony area, playground, open classrooms, social areas, promenade - walking areas, parent waiting area, green areas and parking areas. In some schools, these functions are separated, and in some schools, all functions are used intertwined when necessary due to spatial deficiencies. The space requirements of all functional areas in school gardens, the relationship they establish with each other and the building are different. Under this heading, the design criteria and standards of the functions in the school yard will be expressed.

\section{The Ceremony Area}

The students meet at the ceremony area twice a week, where they also perform recreational activities. Ceremonial areas with Turkish flag and Atatürk bust, which are raised a little from the ground in order to speak, are generally located in the middle of the school gardens where the teachers are able to see and watch the whole school.

The entire garden is covered with concrete to form the area Ceremony evident in many schools in Turkey and is a matter of fairly criticized. School gardens host many activities. Concrete coating of the entire area is a wrong practice. Depending on the activities, non-slip materials, parquet, rubber, gravel should be used and grass, soil and planting should be used for green areas.

The rectangular area in the school garden is rectangular in form, making it suitable for students to line up and settle in branches. According to MEB (2015), $1 \mathrm{~m}^{2}$ per student is sufficient for the ceremony area. The ceremonies are usually held in the school, not in the garden in cold weather. Since there is no separate unit for ceremonies in schools, it is carried out in corridors and sometimes in classrooms. School gardens are arranged according to the climatic conditions and if necessary precautions are taken against natural events such as wind, sun, rain, gardens can be used safely in the winter months. The locations of the ceremony areas in the garden are of great importance in terms of nature conservation.

\section{Area for outdoor sports and playground}

In a study conducted by Burke (2005), children were asked to take pictures of their favorite playgrounds, and as a result, it was observed that the most photographed place was their gardens. According to Titman (1994), students feel better in school gardens compared to closed school spaces and generally consider their time spent in the garden more valuable during their time in school. In this context, school gardens are one of the playgrounds where children spend most of their time. However, the setup of the school playgrounds that we can observe are mostly not specialized spaces for the game, they are units that are shaped according to the composition of indoor and fixed spaces. Even spaces that are not functioned as playgrounds can be included in the game setting for children. However, this spontaneous situation does not satisfy the need for 
specialized playgrounds determined by scientific research and that will positively affect child development.

According to MEB (2015), there should be at least one basketball-volleyball court directed in the north-south direction within the school garden and if possible, 2 basketball hoops should be added for every 300 students. The area around the field should be covered with a wire fence at a minimum height of 5 meters, and adjacent sports fields should be separated from each other with a wire fence.

Most of the school gardens in Turkey have accessories only for football and basketball games. For other children who want to play their own games, it is a negative practice to do these sports in the whole area. For example, the efforts of younger age groups, who do not play basketball in the schoolyard, can turn into a battle for existence. This situation, which is mixed in the same place and causes confusion, does not create a reassuring game environment. Likewise, it is known that girls do not have as much interest in football and basketball games as boys. In a study conducted by G.T. Moore (1986), it was observed that boys in primary school age group generally prefer ball games in asphalt areas and girls prefer natural areas arranged to allow social interaction. In the study conducted by Pellegrini (2005) on gender differences in children, it was revealed that boys prefer games that require more physical activity than girls. In this sense, apart from sports fields, traditional playgrounds such as hopscotch and chess should also be considered and necessary spatial sizes should be separated. Outdoor playgrounds should not only be designed asphalt and should not be closed to change and innovation, and should be constructed in touch with nature. For this purpose, the design of flexible playgrounds that allow innovation and change can be realized with the use of stones, gravel, sand and soil.

\section{Social Areas and Urban Equipments}

School gardens are a representation of the neighborhood's identity. It has been observed that neglected, unqualified school gardens give negative messages about the neighborhood where there are located, and dynamic and active school gardens bring a movement and revitalization to both the school space and the neighborhood (Algan \& Uslu, 2009). The design of urban equipment in the school yard area in Turkey is negligible, unqualified and incompetent elements are used. However, it is a basic human need for individuals to have a healthy continuation of their daily social lives, as well as the necessity to have lighting elements, seating units, game elements, trash cans, and herbal items.

Care should be taken to keep a sufficient amount of space and equipment to allow children to eat and drink something in the school garden in good weather. Eating action can be a focus in establishing social relationships. For this purpose, tables, chairs and picnic units where large groups can sit together can be organized (Stoneham, 1996). Likewise, attention should be paid to the location and design of the seating elements in the design of rest areas in the schoolyard. It is important that the recreational staff are in a position where the children will not feel isolated and isolated from other activities, but can also find a quiet rest. The orientation of the elements according to the wind, sun and noise sources in the garden are also factors to be considered in terms of physical comfort. In this context, resting areas with sheltered and shaded elements that 
are customized within themselves should be designed without being removed from the playgrounds (Stoneham, 1996).
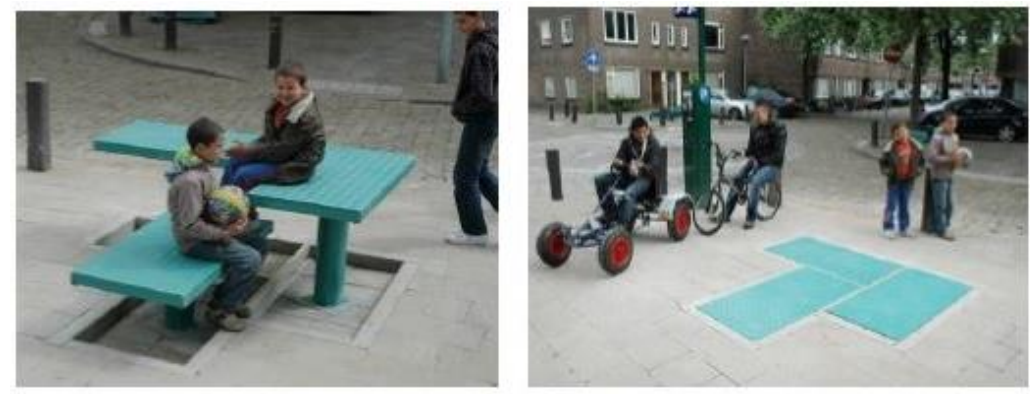

Figure 1. The combination of floor covering and seating element (URL 1)
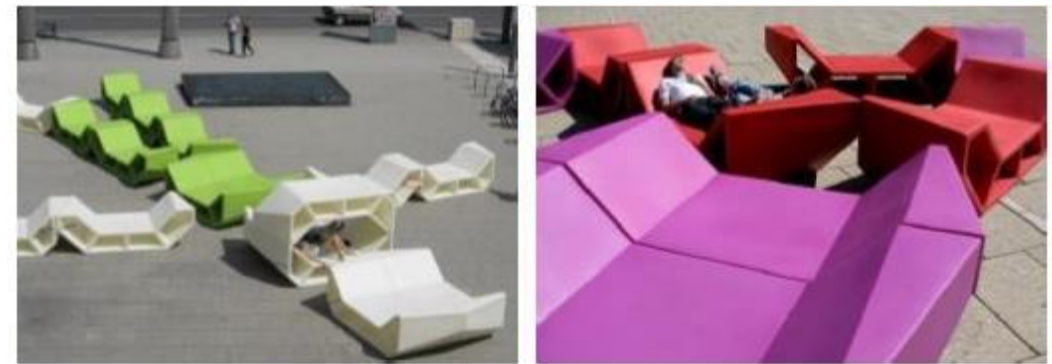

Figure 2. Original seating elements design that can be adapted to the game design (URL 2)

\section{Hiking and Walking Areas}

It is a positive functional activity in establishing schools that live and sustain, which are constructed in harmony with urban fittings in the school garden that can be included in the space as part of social areas and do not intersect with the vehicle. Walking areas should be covered with a smooth, bumpy, durable and non-slip material. The floor covering used should quickly absorb water and dry quickly. If the land is inclined, ramps with a maximum slope of $6 \%$ should be arranged. In mandatory stair use, metal railing and handrail should be made in case of more than 3 steps (MEB, 2015). The construction of the walking paths in the green areas, meeting with the playgrounds and sports fields, and support by the functional and creative urban equipment will make the students come happier and more eager to the school.

\section{Waiting Area for Parents}

In primary schools, the school and parents have a close relationship. Students who do not use a school bus are dropped out and taken to school by their parents. The formation of the places where parents wait and spend time while waiting is in line with the decisions taken by the school management. In some schools, parents are kept in the garden gate of the school, while in some schools, parents are allowed to reach the classroom. 
Educators do not welcome the fact that parents are always present at school, unless they help children access school. The reason for this is the fact that individuals who meet the public space and large social groups during the process that starts with their basic education constantly feel their family surveillance on them, creating a restrictive negative factor in their liberation. It is wrong for parents, who wait and try to keep their children under control at all times, to be in schoolyard, but unfortunately it is an existing situation. Insecurity in the society can cause parents to worry about their children even in the school environment, and to forget the existence and protective attitudes of the management and educators. In order to prevent the parents from joining during the school entrance-exit hours, sitting units used by the staff during the break times can be opened to the use of the parents. Additional units can be added if there is sufficient garden size. These spaces can be used as lecture and recreation units of students and staff with their design flexibility as well (Temel, 2018).

\section{Green Areas}

School gardens need to be designed in accordance with a landscape project that is nature-based and considered in many respects. One of the most important causes of school gardens to look neglected and cold in Turkey is the lack of green spaces. Nature, which is the basic need of all people, is thrown into the background because of the necessities of the city life and a concrete covered environment is created. It is a matter of everyone's responsibility to rescue the educational structures out of this monotony, to create areas to breathe for younger age groups.

Plants can be used to create a control over the visuals and noise while reducing the harmful effects of the wind and exhaust gases. In addition, plants can provide more oxygen needed in sports and playgrounds as well as more livable areas. With vegetation, habitats are created for some insects and birds. Seeing animals in the school yard is important for the physical development of children (Yüce, 2009).

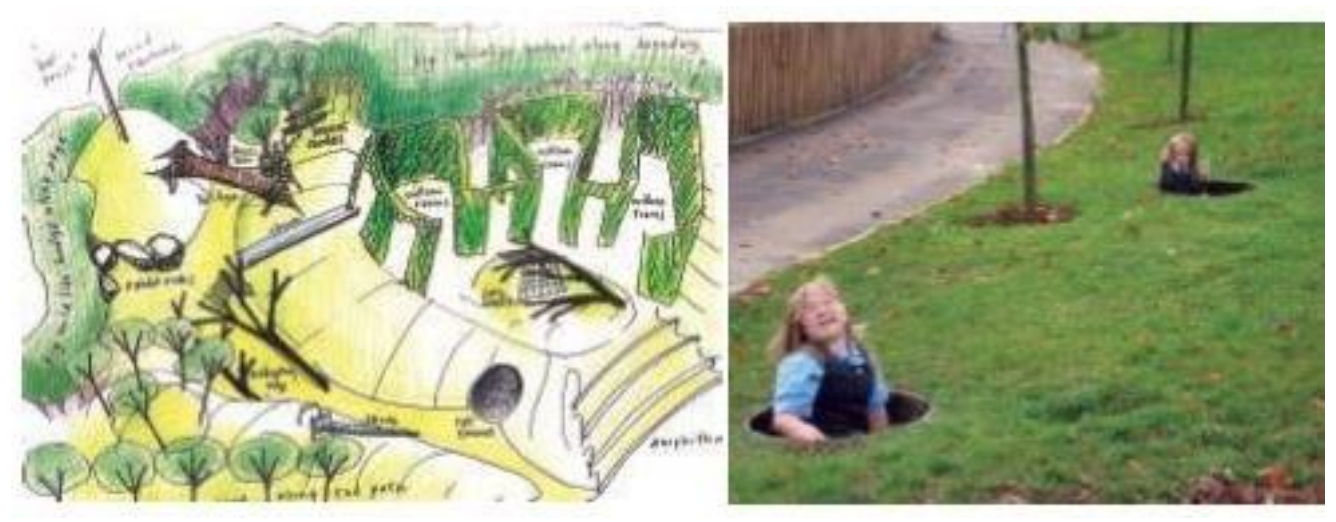

Figure 3. School garden design integrated with nature in Merrylee Elementary (Glasgow, Scotland)

(Finch, 2010) 


\section{MATERIAL AND METHOD}

The study was handled in two stages as a field study after the literature study on the subject. The literature study was carried out to evaluate the land use and physical properties of open breathing areas in primary schools in line with national and international standards. Within the scope of the field study, state schools in Üsküdar district of Istanbul was selected; quantitative and qualitative data were analyzed and graphed and evaluated.

During the analysis, school gardens, ceremonial grounds, playgrounds, parents' waiting areas, open classrooms, social areas, equipment, walking areas, parking lots, and green areas were tabulated and analyzed under separate headings. In fact, in most schools, all functions are used intertwined when necessary. Insufficient space, weather conditions, measures that cannot be taken, and excess student quotas cause different functions to be used together. During the study, the boundaries and uses of these areas were determined and graphed with on-site observations in addition to the architectural drawings of the schools.

\section{FINDINGS}

Of the 39 public primary schools in Üsküdar, 23 of them are standard projects designed by the state, 11 of them are private projects produced by the support of individuals and foundations, 5 of them are repurposed buildings, which were constructed at the end of 1800 s and protected as cultural heritage by the state.

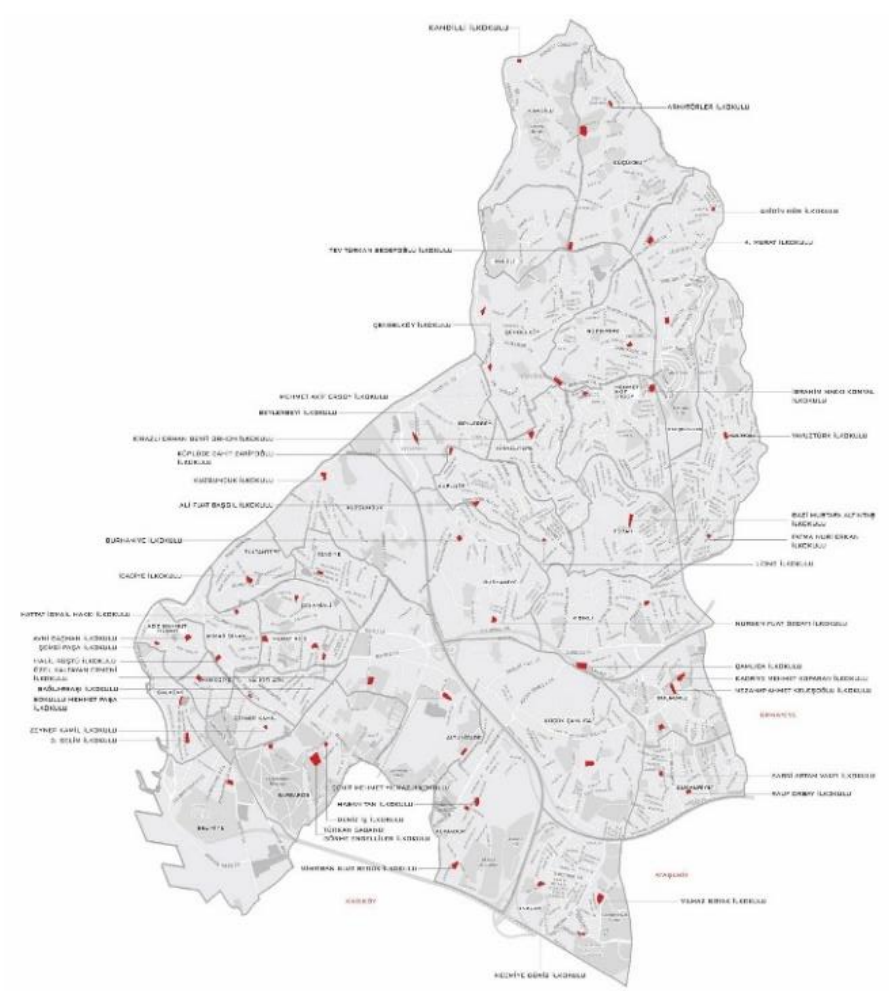

Figure 4. Location of state primary schools on the urban map of Üsküdar district (Temel, 2018) 
Table 1. Numerical data related to the open recreation areas of state primary schools in Üsküdar district (Temel, 2018)

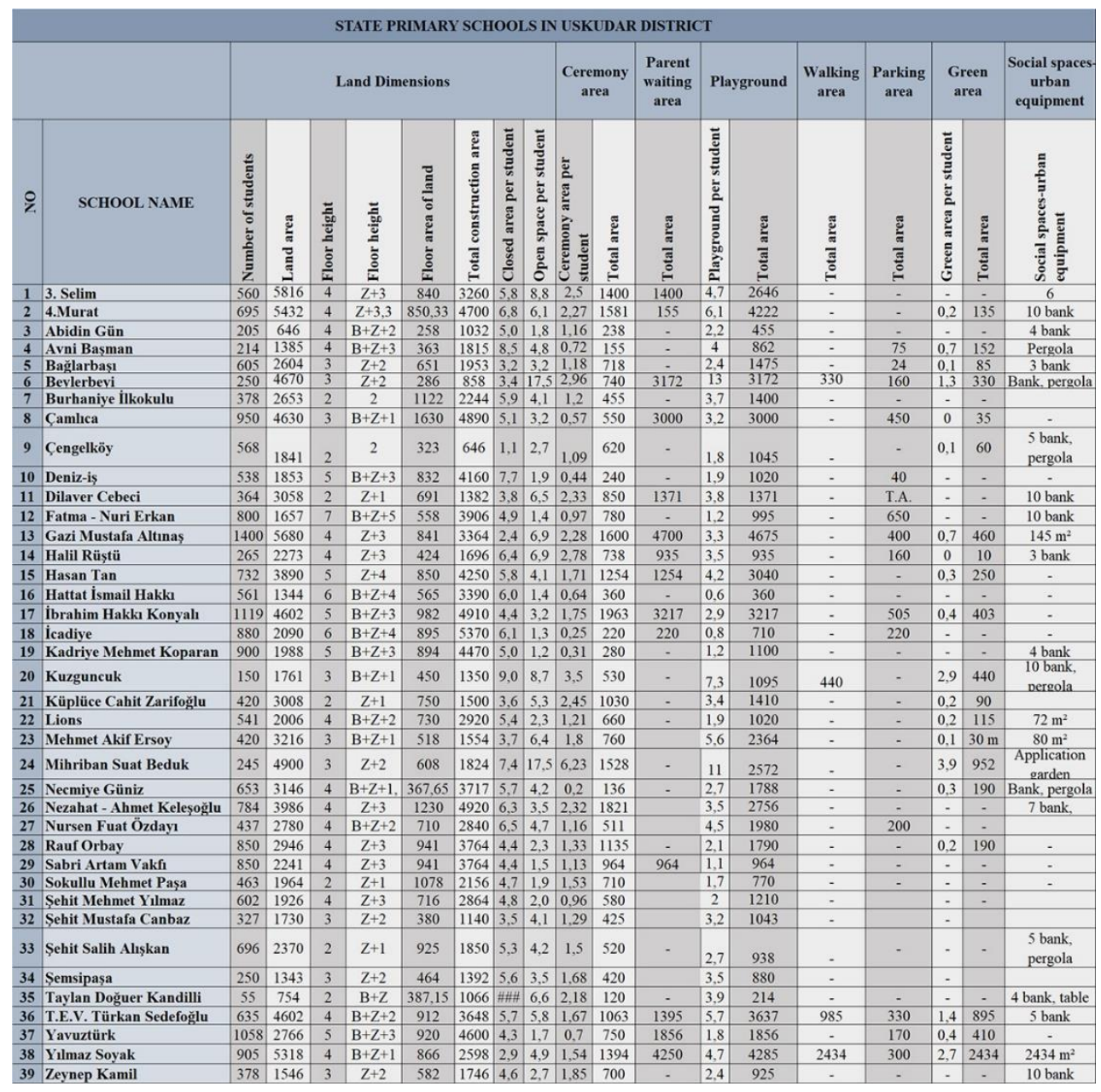

\section{Land Dimensions and Current School Sizes}

The total land size allocated for the official primary education facilities in Üsküdar is $114.310 \mathrm{~m}^{2}$. When the land sizes of the schools were compared, it was observed that Gazi Mustafa Altıntaş Primary School, located in Ferah District, has the largest school area with $5680 \mathrm{~m}^{2}$, and Abidin Gün Primary School, located in Bahçelievler District, has the smallest school land with $646 \mathrm{~m}^{2}$. The average land size of the schools is $2883 \mathrm{~m}^{2} .23$ of 39 schools are below this average.

When the base areas of the schools were compared, it was observed that Çamlica Primary School, which is located in Kis1klı District, has the largest floor area with $1630 \mathrm{~m}^{2}$, and Beylerbeyi Primary School has the smallest floor area with $286 \mathrm{~m}^{2}$. The average of the floor areas of the schools is $726.7 \mathrm{~m}^{2} .19$ of 39 schools are below this average.

When total construction areas are compared, it is seen that the İcadiye Primary School in the İcadiye Neighborhood has the largest construction area with $5370 \mathrm{~m}^{2}$ and the Beylerbeyi Primary School has the smallest construction area with $858 \mathrm{~m}^{2}$. The average construction area of the schools is $2812 \mathrm{~m}^{2} .19$ out of 39 schools are below this average. Schools have an average of 4 floors. 16 of 
them are below average and 8 of them are above average. Schools have an average of 4 floors. 16 of them are below average while 8 of them are above it.

\section{Open Areas of Use}

In general, the open area per student is highest with 17.5 people $/ \mathrm{m}^{2}$ in Beylerbeyi Primary School and Mihriban Suat Bedük Primary School, which is located at Acıbadem district, and the lowest open area per student with 1.2 persons $/ \mathrm{m}^{2}$ is in Kadriye Mehmet Koparan Primary School in Bulgurlu District. The average rate in Üsküdar is 4.5 people $/ \mathrm{m}^{2}$. It was observed that $49 \%$ of the schools were low, 26\% were average, $20 \%$ were high, and 5\% were the highest values.

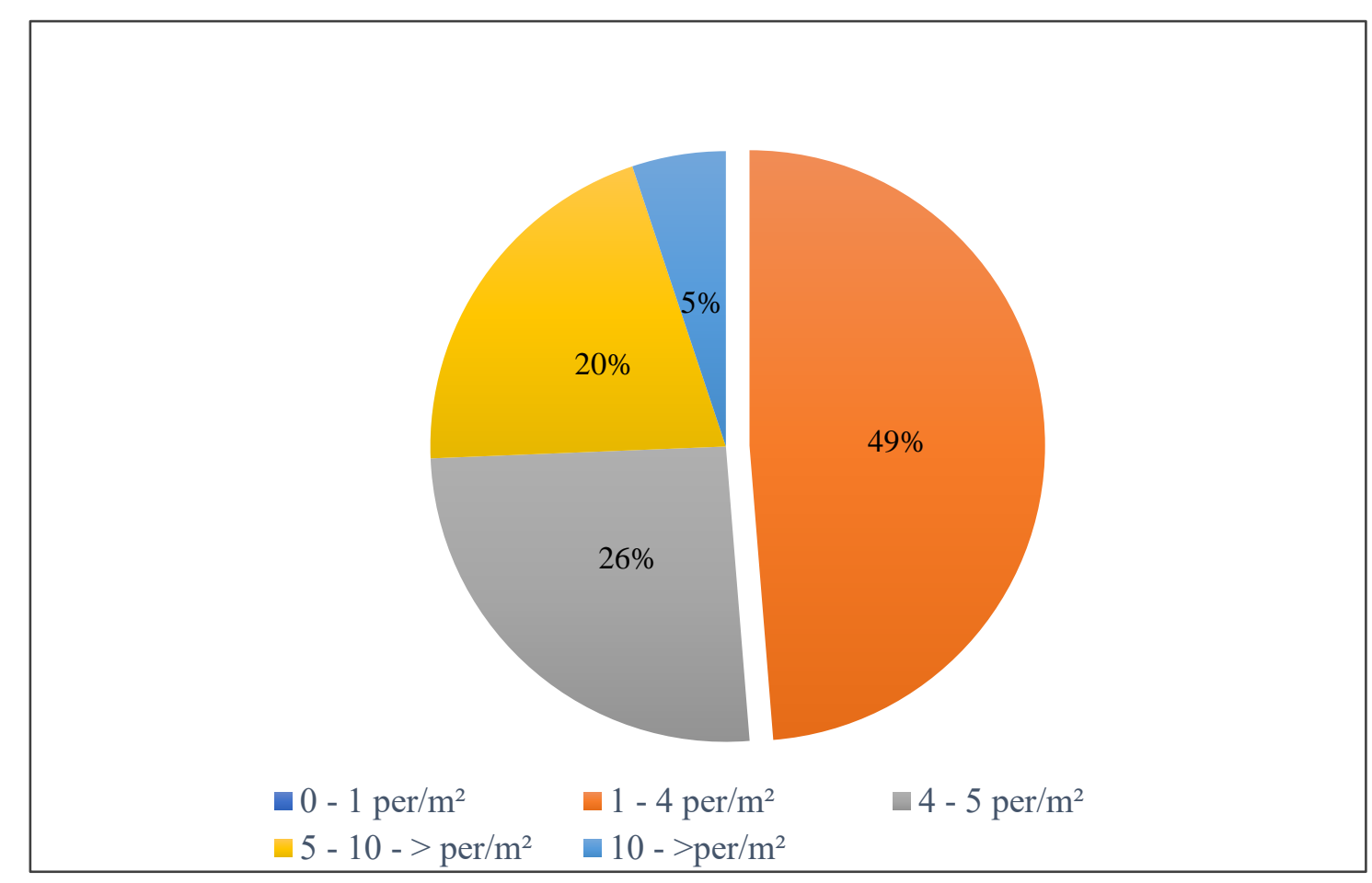

Figure 5. Outdoor usage area per student 
Table 2. Mihriban Suat Bedük Primary School Site Plan (Left), Beylerbeyi Primary School Site Plan (Middle), Kadriye Mehmet Koparan Primary School Site Plan (Right) (Temel, 2018)

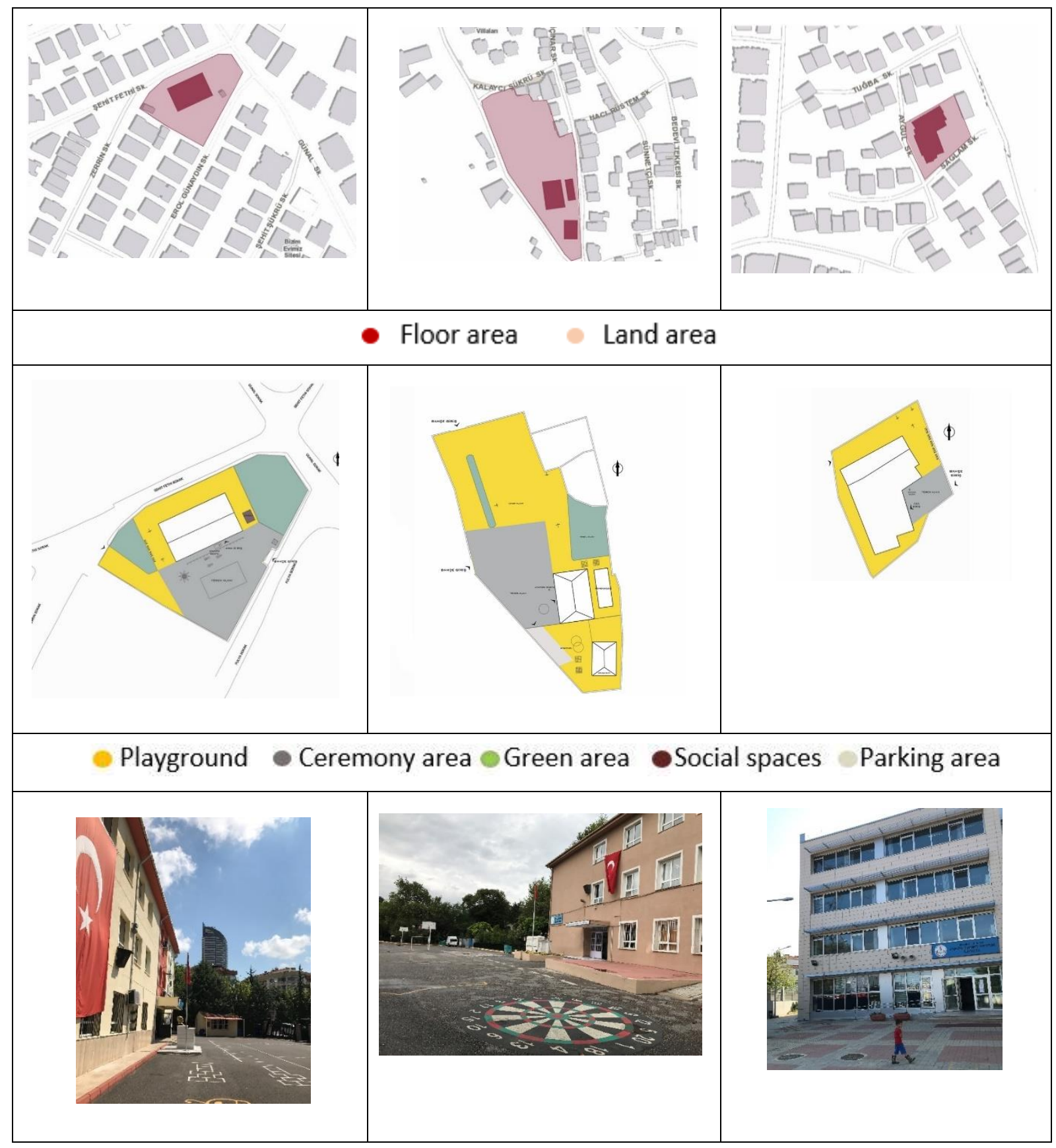

\section{Ceremony Area}

The ceremony area is the largest with $1821 \mathrm{~m}^{2}$ in Nezahat Ahmet Keleşoğlu Primary School, located in Bulgurlu Mahallesi, and the smallest with $120 \mathrm{~m}^{2}$ in Taylan Doğuer Kandilli Primary School, while the average ceremony area size is $782 \mathrm{~m}^{2} .26$ of 39 schools are below average. The size of the ceremonial area per student is the largest in Mihriban Suat Bedük Primary School in Acrbadem District with 6,23 people / $\mathrm{m}^{2}$, and the smallest in Necmiye Güniz Primary School in 
Ünalan District with 0,2 people / $\mathrm{m}^{2}$ while the average rate in Üsküdar is 1.6 people $/ \mathrm{m}^{2}$. It was observed that $28 \%$ of the schools had very low, $44 \%$ low, $26 \%$ average, and $2 \%$ high values.

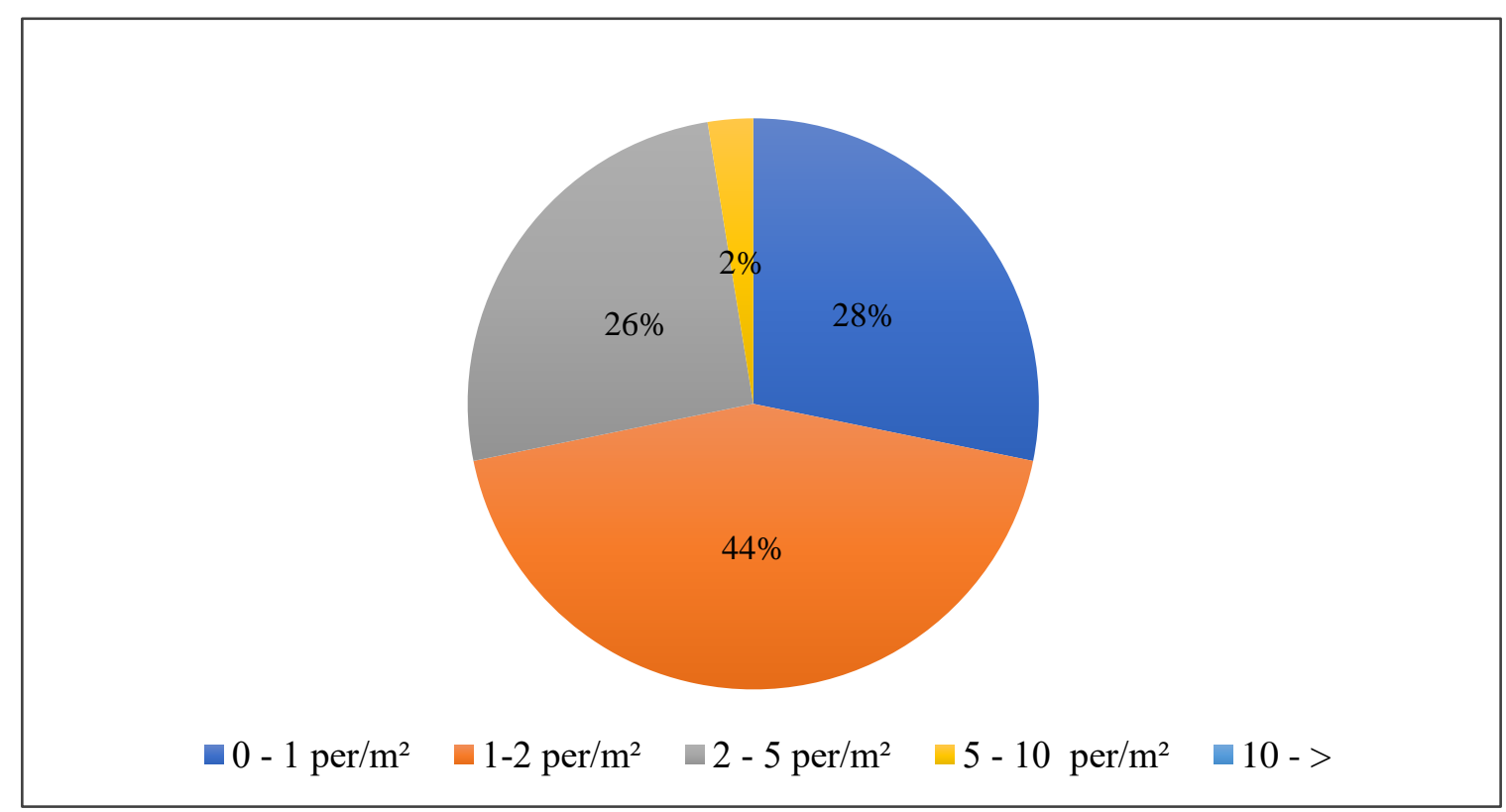

Figure 6. Ceremonial area per student 
Table 3. Mihriban Suat Bedük Primary School (left), Necmiye Güniz Primary School (right) (Temel, 2018)

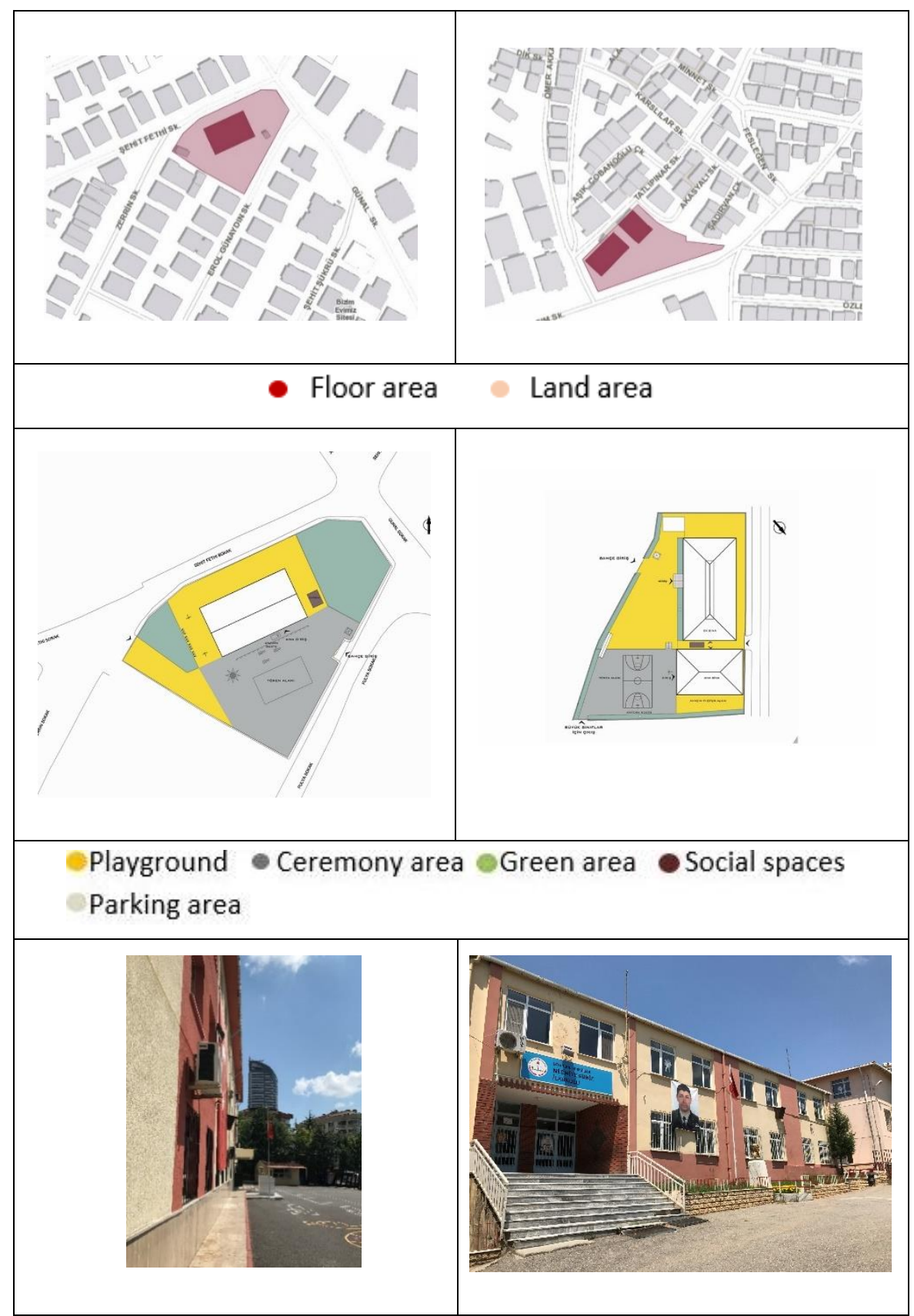

\section{Playground}

The playground is the largest with $4250 \mathrm{~m}^{2}$ in Yilmaz Soyak Primary School in Ünalan Mahallesi and the smallest with $214 \mathrm{~m}^{2}$ in Taylan Doguer Kandilli Primary School, while the average playground size is $1778 \mathrm{~m}^{2} .23$ of 39 schools are below average. The average playground area per student is the largest at Beylerbeyi Primary School with 12.68 people $/ \mathrm{m}^{2}$, while Hattat İsmail Hakk1 Konyalı Primary School is the smallest with 0.64 people $/ \mathrm{m}^{2}$, while the ratio across Üsküdar 
is 3.5 people $/ \mathrm{m}^{2}$. It was observed that $5 \%$ of schools have very low, $41 \%$ are low, $26 \%$ are average, $23 \%$ are high, and $5 \%$ are highest values.

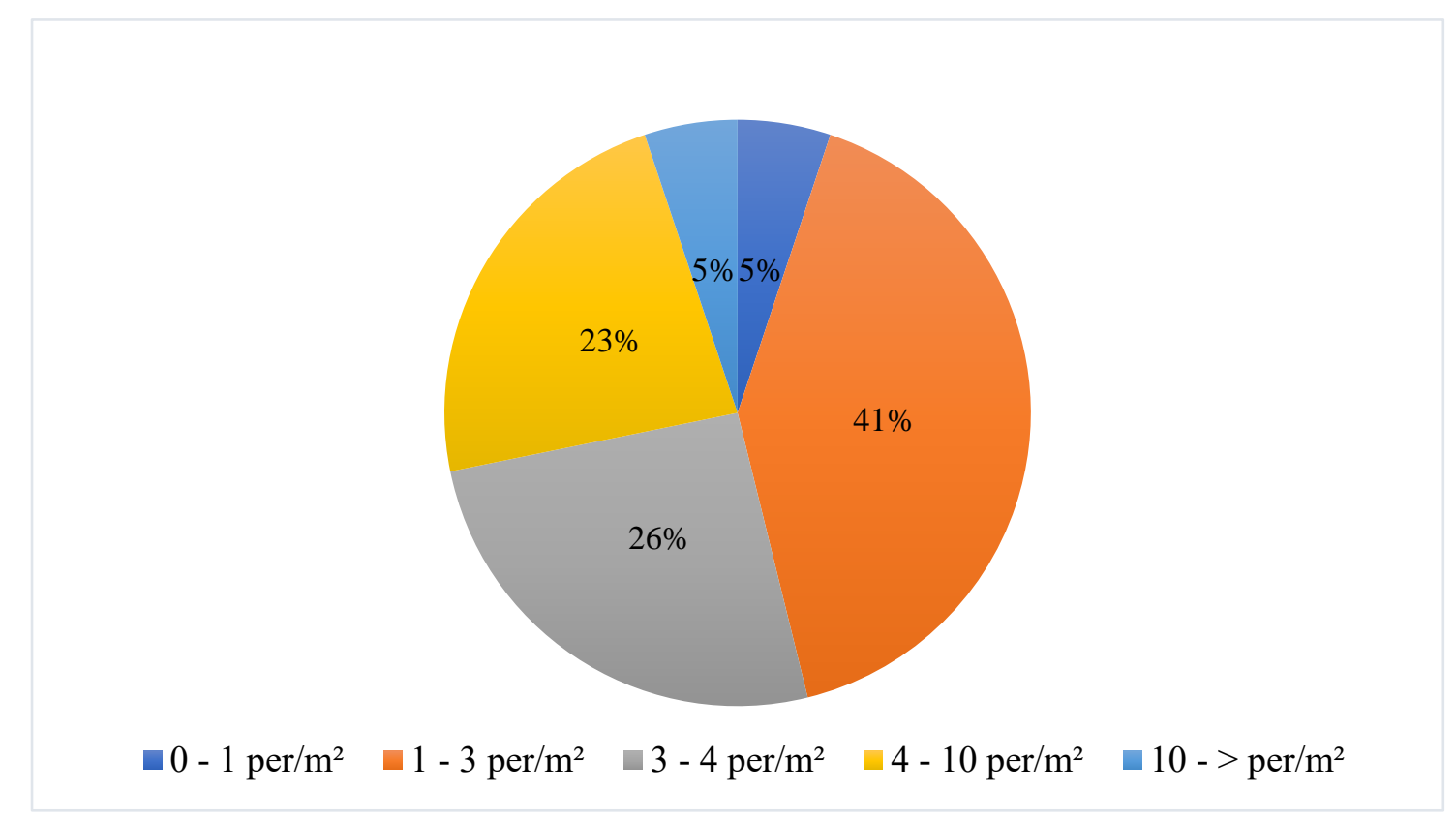

Figure 7. Playground area per student 
Table 4. Beylerbeyi Primary School (left), Hattat İsmail Hakkı Primary School (right) (Temel, 2018)

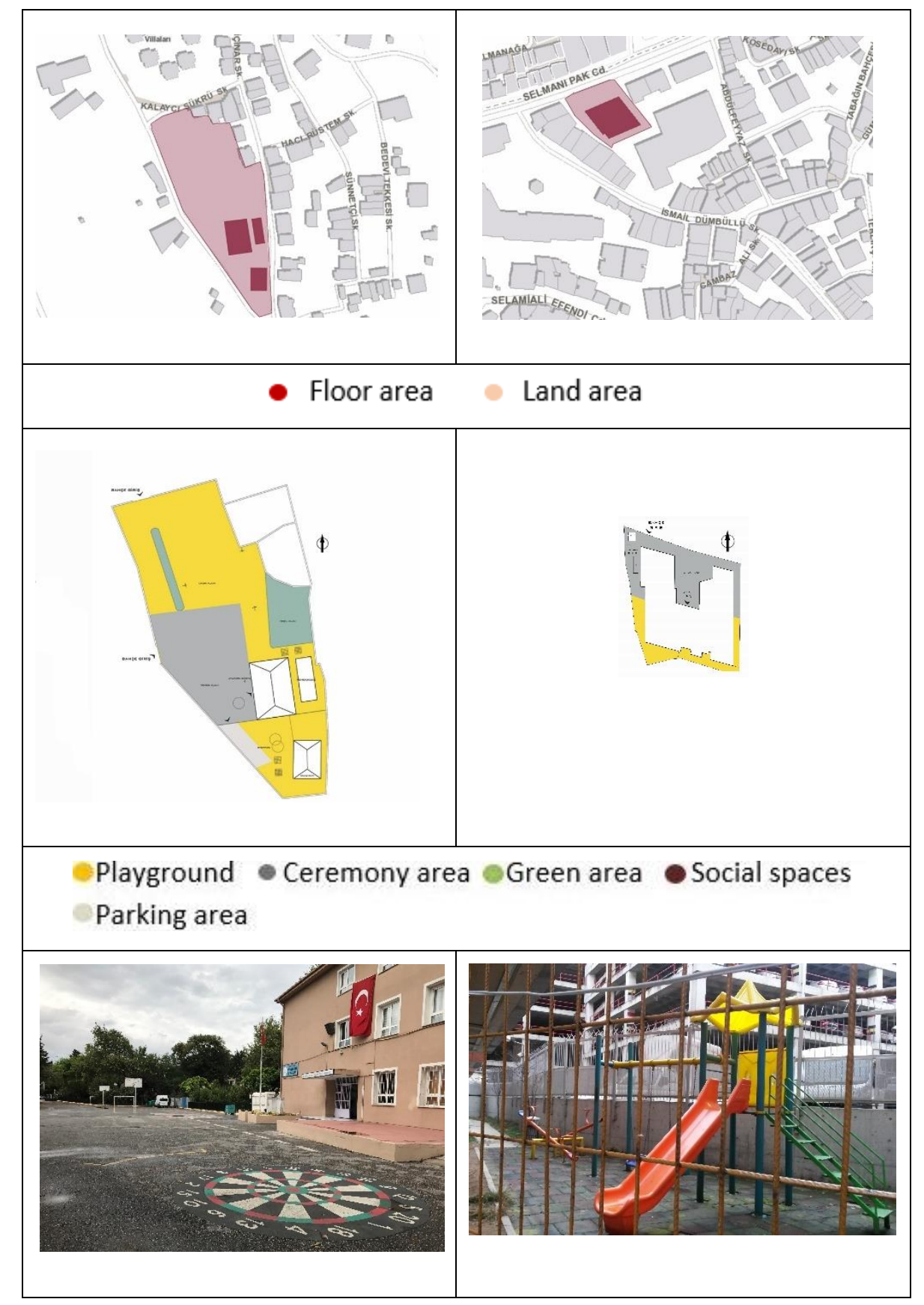

\section{Green Areas}

20 of the schools in the study area have green areas. The largest green area is in Yllmaz Soyak Primary School with $2434 \mathrm{~m}^{2}$. The green area of Yilmaz Soyak Primary School is arranged in harmony with social areas and walking areas. There is an area of 2.68 people $/ \mathrm{m}^{2}$ per student. The amount of green area per student in Üsküdar is 0.8 people $/ \mathrm{m}^{2}$. 


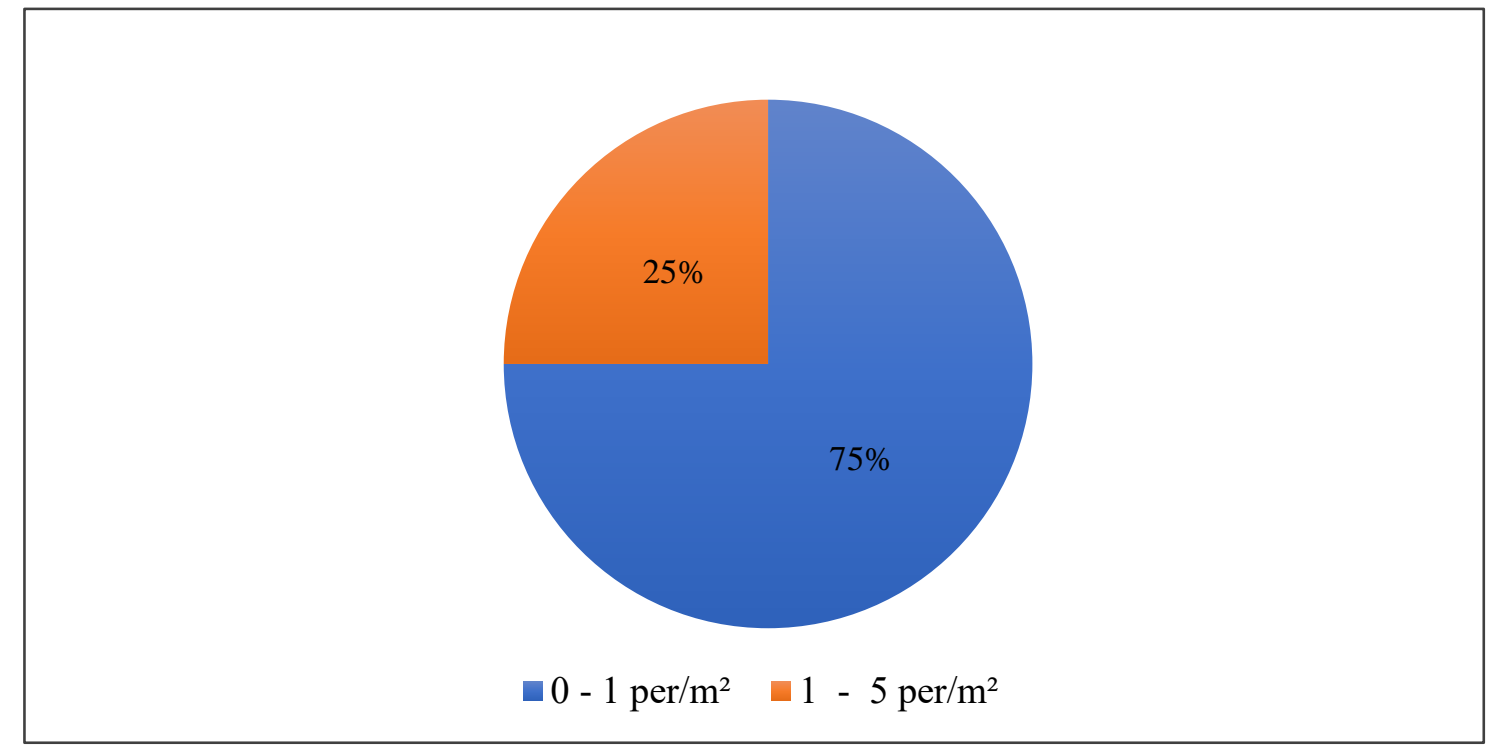

Figure 8. Green area per student

Table 5. Y1lmaz Soyak Primary School (Temel, 2018)

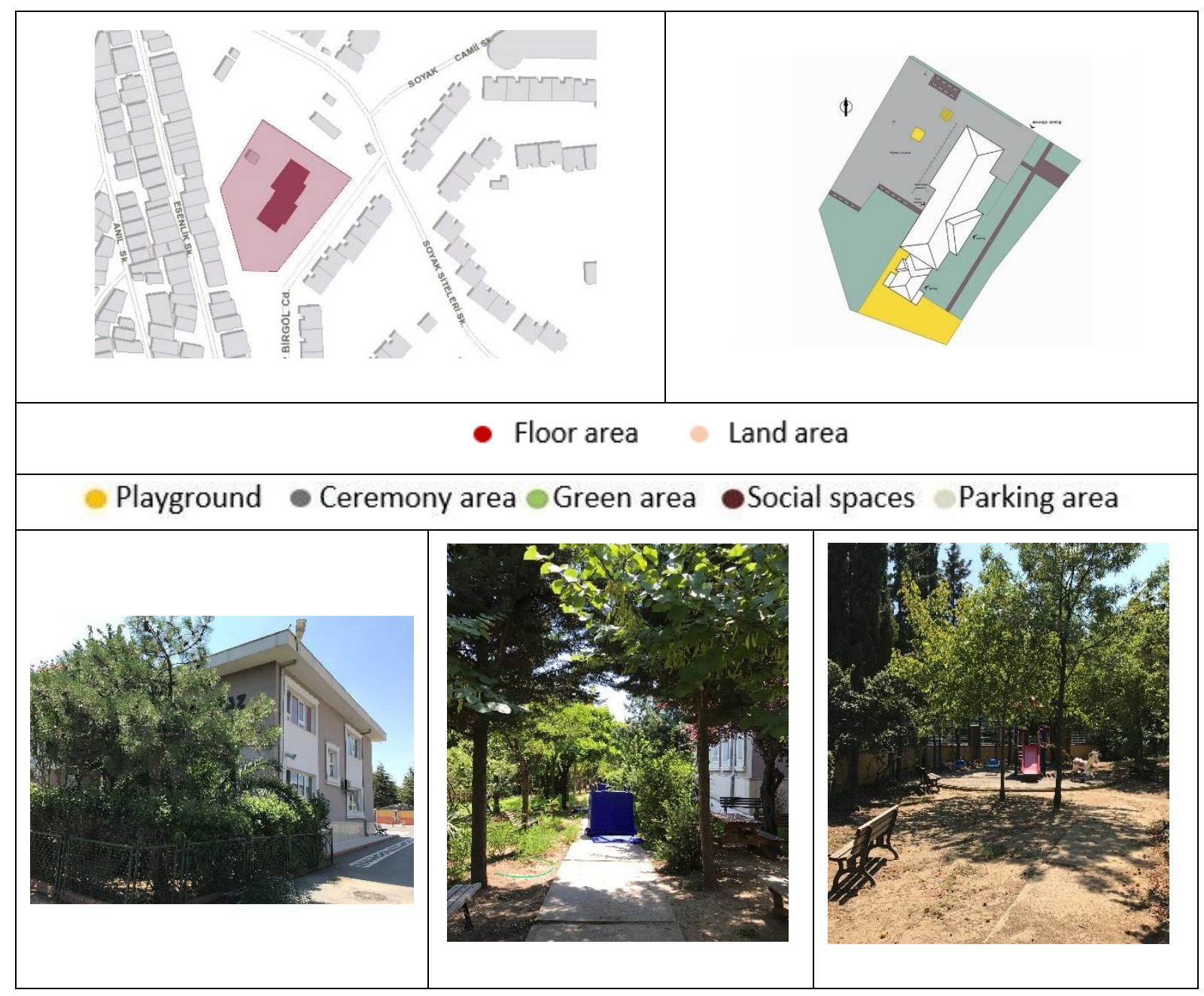




\section{Parking Areas}

As a result of interviews with the school principals, it was learned that hardly any of the schools wishes to allow the use of the ceremony area by vehicles. Of the 39 primary schools in Üsküdar, 24 of them do not allow anybody, including the staff, to enter the school garden with their vehicles. School services are allowed for a period of 5-10 minutes, as it is considered dangerous for younger age groups to wait outside the school only during school leaving hours. There are 16 schools in Üsküdar. The biggest parking area is in Fatma Nuri Erkan Primary School in Yavuztürk District. Empty land next to the school is used for the parking lot for the vehicles of the staff and guests and it is $650 \mathrm{~m}^{2}$ in size.

Table 6. Fatma Nuri Erkan Primary School (Temel, 2018)

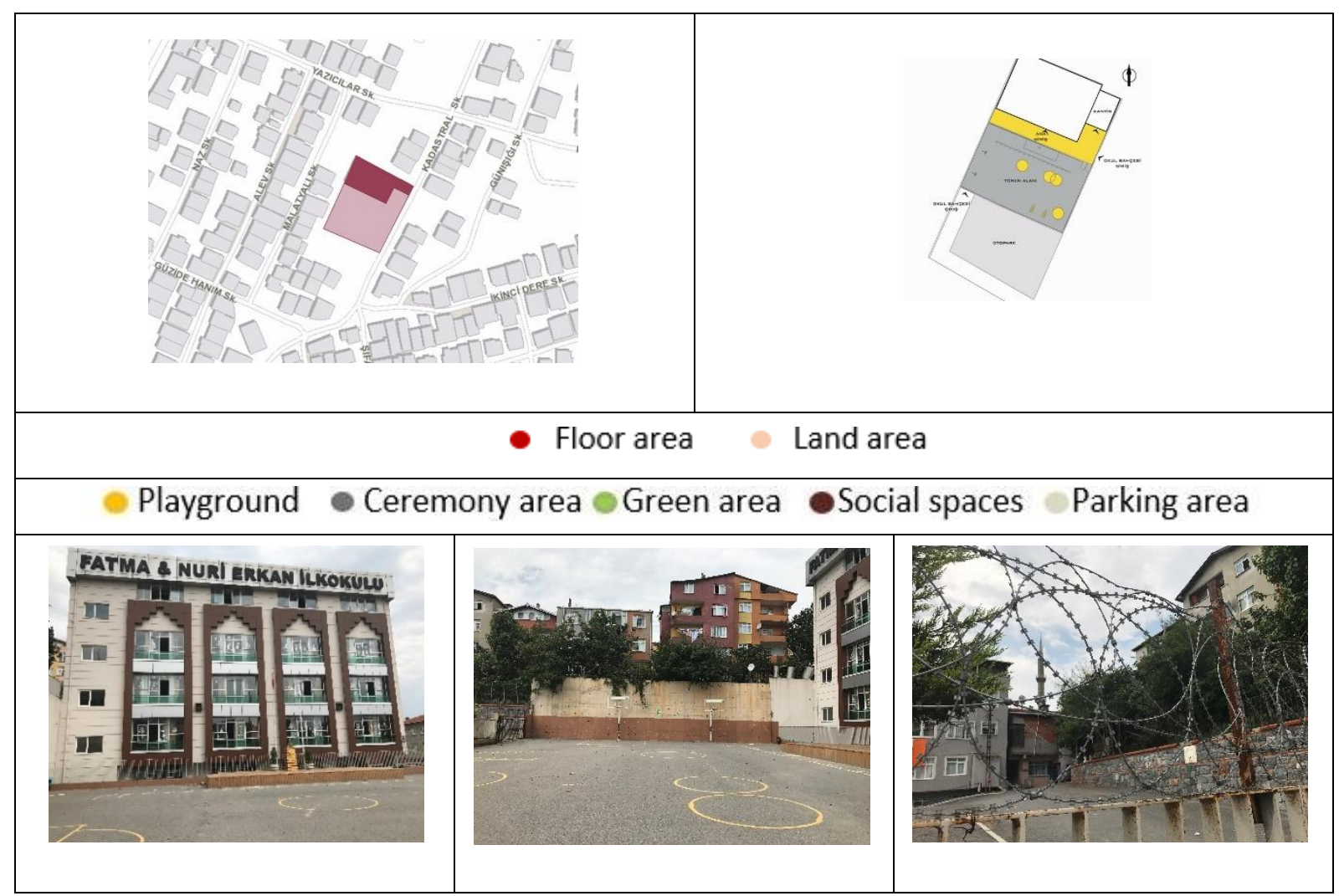




\section{Social Spaces, Urban Equipment}

It was observed that the social areas and equipment, which are the places where students will spend time, sit and rest apart from chatting outside the games, are insufficient in line with the primary schools examined. All school gardens have tried to solve this problem by using a few benches and in some schools with a canopy for staff to use in good weather.
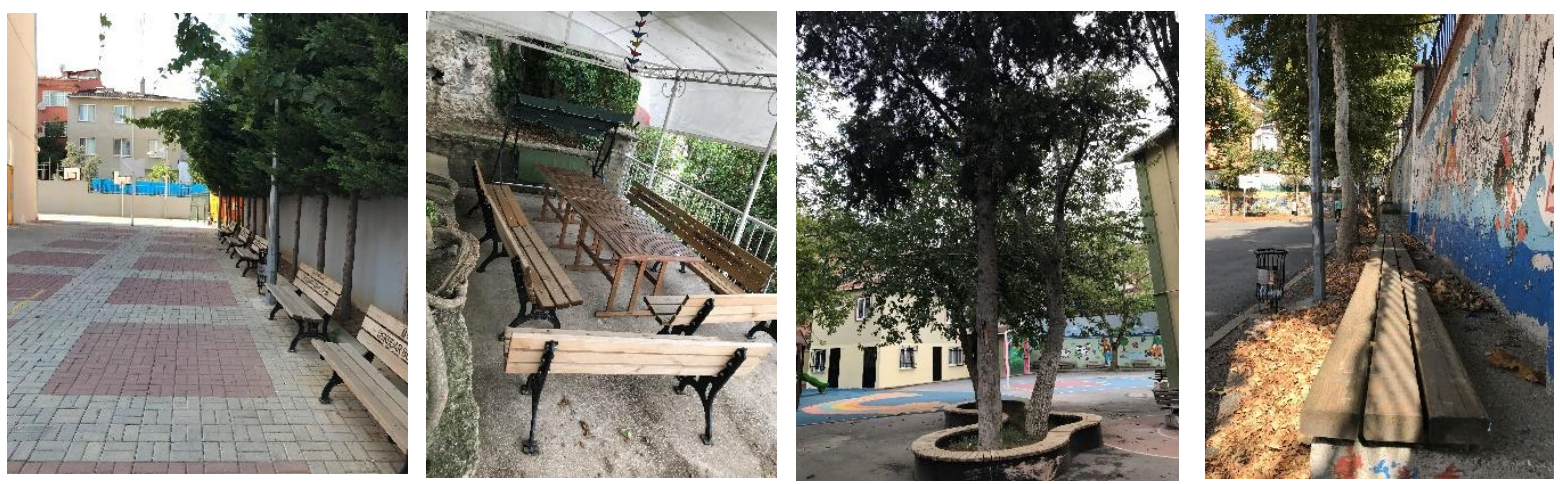

Figure 9. Kuzguncuk Primary School, Mehmet Akif Ersoy Primary School, Kadriye Mehmet Koparan Primary School, Lions Primary School (Temel, 2018)

\section{Parent Waiting Area}

During the interviews with the school administrators in Üsküdar, it was learned that the majority of the schools did not want the parents' entrance to the school except for the special situations and parent meetings that concern the student and took restrictive measures in this regard. Parents who are prevented from entering schools unless they get their permission during the day, are taken into the garden at 14 of 39 schools at the time of school entrance and exit. Apart from these hours, their entrance to the school is prevented by the administration unless it is compulsory. In some schools, parents who are taken into the garden at the time of entry and exit are allowed to wait only in the ceremony areas, while in some schools, they are allowed to enter the building. A special area is reserved for the parents to wait only in the garden of the 4th Murat Primary School. This parent waiting area, separated by a border expressed only as a line on the ground, is $155 \mathrm{~m}^{2}$ in size. Seating units and shaded elements where parents can rest while waiting are not found in any schools, including 4. Murat Primary School. 


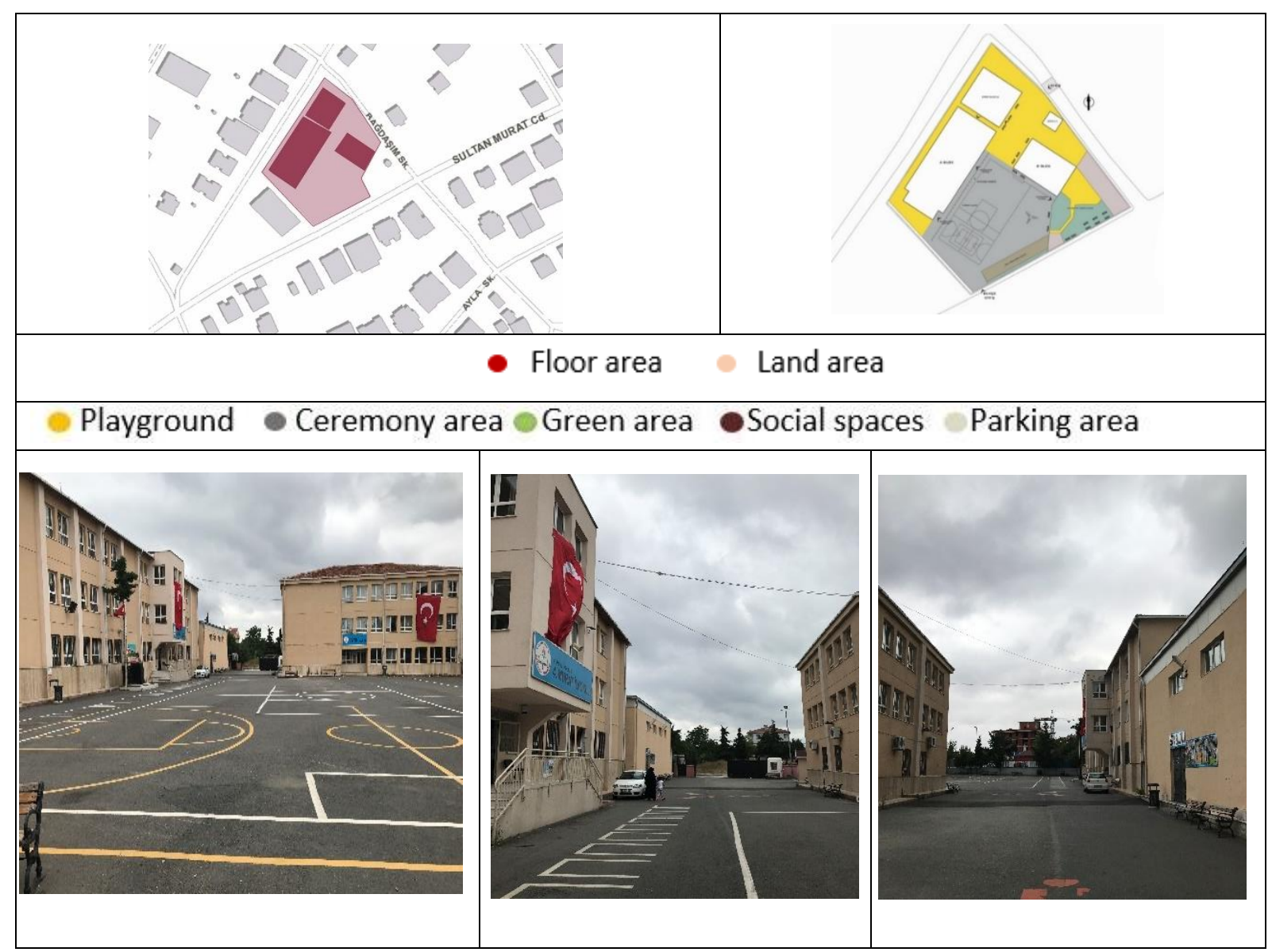

\section{EVALUATION AND CONCLUSION}

As a result of the study conducted in the official primary schools in Üsküdar district of Istanbul, it was observed that the open areas of use per student in general were lagging behind the existing practices selected from various countries. In addition, the majority of the schools in this research do not have any semi-open spaces in their gardens. In schools where a precaution is not taken for rains in the winter and spring months, the managements found the solution to this problem by not allowing the students to play in the garden during the rainy period. The interaction of students with nature and open spaces is of great importance in the development process. In this context, school gardens should have semi-open spaces suitable for adverse weather conditions.

Asphalt was used as hard flooring in all of the schools' gardens in the study area. This is due to the fact that creating a ceremony area in school gardens with limited use is considered a priority. The ceremony areas created in this context have the same design as all of Üsküdar. The playgrounds in the school gardens are the part used as a ceremony area, it is not a separated space. The use of materials such as natural stone, wood, rubber and grass were not encountered in the playgrounds. This causes injuries in falls during play and negatively affects children's comfort with regard to space use. In terms of spatial size per student, most schools remain below average and have 
insufficient usage areas. Equipment was also found insufficient for the game, which was the most preferred action of students during recess time.

Access to the school yard is prohibited in the majority of the schools surveyed. In some schools, only student services are allowed for school entry and exit times. This is a necessary precaution for schools that do not have specialized parking lots. Similar to the prohibition of entrance to the school, parents are not allowed to wait in the school yard outside the entrance and exit hours in most schools. This is a measure taken by the management to ensure the adaptation of the students. In most of the schools that accept the parents to the school yard during the entrance and exit hours, there is no special design for waiting parents. Only at 4th Murat Primary School, a special space is reserved for parents to wait. However, this distinction is only indicated by a line on the floor and is not suitable for sitting and resting.

Similarly, social spaces and urban facilities constitute a major deficiency in the schools examined. In most schools, seating and relaxation areas are not defined for leisure activities. The equipment used is also inadequate in number and quality. On the other hand, the urban facilities used in the rest areas are only benches and, in rare cases, canopies.

The greatest deficiency in schools' gardens is observed in green areas. The amount of green space per student is quite low. The green area design that can be used with playgrounds, social areas and walking areas has been observed only in Yilmaz Soyak Primary School. This result is very sad and brings many negativities. However, the use of green spaces in school gardens would enable visual richness, create noise control, reduce the effect of harmful gases and provide more oxygen for sports and playgrounds.

As a result, school gardens where children spend most of their days should be designed to support their physical, mental and cognitive development. Spatial solutions that support development are rarely seen in the schools studied. The fields per student should be increased with qualifications.

\section{REFERENCES}

Aksu, Ö. V. \& Demirel Ö. (2011). The design and land usage of the primary school gardens in Trabzon. Süleyman Demirel University Faculty of Forestry Journal, 12, 40-46.

Algan, H. \& Uslu, C. (2009). Designing Primary Schoolyards with the Stakeholder Participation: Adana Sample." Mediterranean Agricultural Sciences, 22(2), 129-140.

Bradley, L.K. (1995). Tierra Buena, the creation of urban wildlife habitat in an elementary school in the inner city. Children's Environments, 12(2), 102-110.

Bunting, T.E. \& Cousins L.R. (1985). Environmental dispositions among school-age children: A preliminary Investigation. Environment and Behavior, 17(6), 725-68.

Burke, C. (2005). Play in focus: children researching their own spaces and places for play. Children, Youth and Environments, 15(1), 27-53.

Çetiner, A. (1972). Şebircilik Çalssmalarnda Donatım İlkeleri. Istanbul: Istanbul Technical University Printing House. 
Erdönmez, İ. M. Ö. (2007). Landscape Designing Norms for Elemantary School Gardens. Istanbul University Journal of Forestry Faculty, 57(1), 107-122.

Harvey, M.R. (1989). The Relationship between children's experiences with vegetation on school grounds and their environmental attitudes. Journal of Environmental Education, 21(2), 9-15.

http://www.toxel.com/tech/2011/03/12/pop-up-street-furniture/ erişim tarihi 23.10.2017

http:/ / flexiblecity.wordpress.com/2011/03/27/urban-furniture/ erişim tarihi 14.09.2017

Karabey, H. (2004). Eğitim Yapılar: Geleceğin Okullarm Planlamak ve Tasarlamak Cağdas Yaklaşımlar, Ilkeler. Literature Publishing, Istanbul.

Kelkit, A. \& Özel, E. (2003). A research on the determination of physical planning of school gardens in Çanakkale city. Pakistan Journal of Applied Science, 3(4), 240-246.

Kellert, S.R. (1985). Attitudes toward animals: age-related development among children. Journal of Environmental Education, 16(3), 29-39.

MEB. (2015) Eğitim Yapılar Asgari Tasarım Standartlar 2015 Yı Kılavuఇu. Milli Eğitim Bakanlığı, Ankara.

Moore, G. T. (1986). Effects of the spatial definition of behavior settings on children's behavior: a quasi-experimental field study. Journal of Environmental Psychology, 6(3), 205-231.

Özdemir, A. \& Y1lmaz, O. (2009). Investigation of the Effects of Primary School Gardens on Child Development and Healthy Life. Journal of National Education, 181, 121-130.

Özgen, Y. \& Aytuğ, A. (1992). A review of children's playgrounds and tools in terms of user trends. Istanbul University Journal of Forestry Faculty, 42(2), 99-118.

Özyaba, M. (1998). Define of Design Criterias and The Standarts of Open Areas of Elemantary School. MSc. Thesis, Karadeniz Technical Unversity, Trabzon.

Özyorgun A. \& Batuk F. (2007). Trabzon Explication of Public Facility Standards of Primary Schools and The Application by GIS TMMOB HKMO National CBS Congress, Karadeniz Technical University, October.

Pellegrini, A. D. (2005). Recess: Its role in education and development. Psychology Press, London.

Stoneham, J. (1996). Grounds for Sharing: A Guide to Developing Special School Sites. Learning through Landscape Trust, United Kingdom.

Temel, S. C. (2018). Site Plan Decisions of Primary Schools and Effects on The Design of Open-Closed Break Areas as a Place of Education. MSc. Thesis, Mimar Sinan Fine Arts University, Istanbul.

Titman, W. (1994). Special places; special people: The bidden curriculum of school grounds. Godalming: World Wide Fund for Nature.

Yılmaz, O. \& Ertürk, F. (2016). Çanakkale Kent Merkezindeki Kamusal Açık Yeşil Alanlardan Okul Bahçelerinin Yeterlilikleri Üzerine Bir Araştırma. Çanakkale Onsekiz Mart Üniversitesi Fen Bilimleri Enstitüsü Dergisi, 2(2), 45-55.

Yüce, N. (2009). The Assesment of Convenience of the Physical Conditions In Elementary Schools To Educational Programs And Student Requirements. MSc. Thesis, Yeditepe University, Istanbul. 
Zengin, F. (2015). Evaluation of Primary Schools' Open Space Performance and Design Principles for Schoolyards. PhD Thesis, Istanbul Technical University, Istanbul.

\section{VISUAL DOCUMENT SUBTITLES}

Figure 1. The combination of floor covering and seating element (URL 1)

Figure 2. Original seating elements design that can be adapted to the game design (URL 2)

Figure 3. School garden design integrated with nature in Merrylee Elementary (Glasgow, İskoçya) (Finch,2010)

Figure 4. Location of state primary schools on the urban map of Üsküdar district (Temel, 2018)

Figure 5. Outdoor usage area per student

Figure 6. Ceremonial area per student

Figure 7. Playground area per student

Figure 8. Green area per student

Figure 9. Kuzguncuk Primary School, Mehmet Akif Ersoy Primary School, Kadriye Mehmet Koparan Primary School, Lions Primary School (Temel, 2018)

Table 1. Numerical data related to the open recreation areas of state primary schools in Üsküdar district (Temel, 2018)

Table 2. Mihriban Suat Bedük Primary School Site Plan (Left), Beylerbeyi Primary School Site Plan (Middle), Kadriye Mehmet Koparan Primary School Site Plan (Right) (Temel, 2018)

Table 3. Mihriban Suat Bedük Primary School (left), Necmiye Güniz Primary School (right) (Temel, 2018)

Table 4. Beylerbeyi Primary School (left), Hattat İsmail Hakk1 Primary School (right) (Temel, 2018)

Table 5. Yilmaz Soyak Primary School (Temel, 2018)

Table 6. Fatma Nuri Erkan Primary School (Temel, 2018)

Table 7. 4. Murat Primary School (Temel, 2018)

\section{BIOGRAPHY OF THE AUTHOR}

\section{Selda Cansu Temel}

The author is graduated from the Department of Architecture at Karadeniz Technical University in 2014; and completed her master program at Mimar Sinan Fine Arts University in 2018. She has been a Ph.D student in Architectural Design Program in Yildız Technical University and a research assistant in the Faculty of Architecture at Karabük University. Her main research interests are design, architectural design, architectural psychology, space perception and education buildings. 